\title{
ASPECTOS DE LA VIOLENCIA EN LOS DRAMAS DE CALDERÓN
}

\author{
Ignacio Arellano \\ GRISO-Universidad de Navarra \\ [Anuario calderoniano (ISSN: 1888-8046), 2, 2009, pp. 15-49]
}

Un conocido fragmento de Heráclito afirma que la guerra es la madre de todas las cosas; de la formulación de Petrarca («Sine lite atque offensione nihil genuit natura parens») recogerá la idea más tarde $\mathrm{La}$ Celestina, cuyo prólogo desarrolla el tópico con lujo de ejemplos ${ }^{1}$ :

Todas las cosas ser criadas a manera de contienda o batalla dice aquel gran sabio Heráclito [...] esto con que nos sostenemos, esto con que nos criamos y vivimos, si comienza a ensoberbecerse más de lo acostumbrado, no es sino guerra.Y cuánto se ha de temer manifiéstase por los grandes terremotos y torbellinos, por los naufragios y encendios, así celestiales como terrenales, por la fuerza de los aguaduchos, por aquel bramar de truenos, por aquel temeroso ímpetu de rayos [...] Pues entre los animales ningún género carece de guerra: peces, fieras, aves, serpientes, de lo cual todo una especie a otra persigue [...] aun la mesma vida de los hom-

\footnotetext{
${ }^{1}$ La Celestina, pp. 15 y ss.
} 
bres, si bien lo miramos, desde la primera edad hasta que blanquean las canas, es batalla.

La guerra, los conflictos, la violencia en suma, en la que antropólogos y críticos como Girard han visto el fundamento y la matriz de todas las significaciones míticas y rituales ${ }^{2}$ de la cultura humana, prolifera extraordinariamente en los dramas calderonianos y contagia a numerosos personajes, desde los tiranos patológicos hasta los héroes capaces de vencerla por la superación y el control, obedientes a imperativos éticos de índole religiosa o a criterios del heroísmo aristocrático y filosofias neoestoicas. Cada uno de esos personajes, situaciones y conductas, revela en Calderón una densa complejidad que en estas páginas solo puedo apuntar, en un modesto intento de trazar un cuadro muy general de las formas de violencia en el corpus referido.

\title{
La guerra omnipresente
}

La expresión más intensa de la violencia es la guerra entre naciones, y sobre todo la guerra civil, intestina. La primera puede contribuir a la unidad de cada una de las partes enfrentadas, al reforzar su identidad frente al enemigo; la segunda supone la desintegración total. En casi todos los dramas de Calderón la guerra constituye el modo más amplificado de la violencia, pero no siempre aparece de la misma forma. Una modalidad especial es la guerra santa: la de los Macabeos contra los impíos asirios (Judas Macabeo), la de David contra los varios enemigos de Israel (Los cabellos de Absalón), o de los portugueses contra los moros (El príncipe constante)... No es menos violenta que otras, pero obedece a los mandatos de Dios, que la justifican y le imponen fronteras. Tolomeo en Judas Macabeo exalta el valor de Judas y su violencia liberadora de Jerusalén; la sangre, el castigo, la destrucción, son los motivos centrales de este lenguaje de la violencia al que volveré a referirme:

\author{
Valiente Macabeo, \\ dichoso defensor del pueblo hebreo,
}

${ }^{2}$ Ver Girard, 1983, p. 121. Como apunta Llano, 2004, p. 123 es incuestionable que la violencia ha acompañado el inicio y desarrollo de toda cultura. 


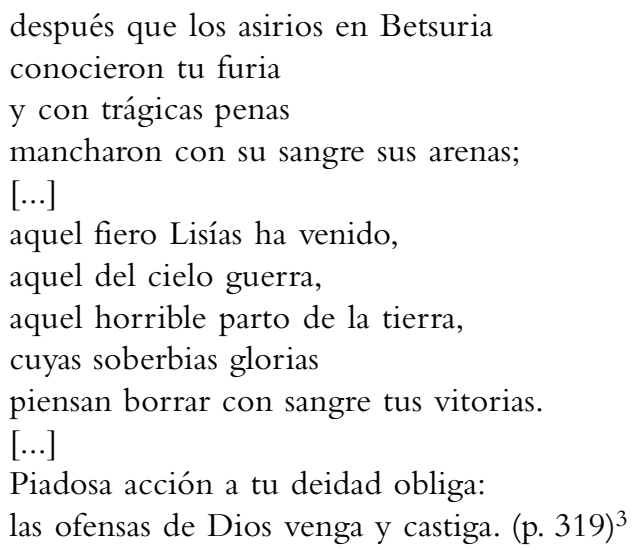

Frente a esa violencia santa todos los demás enfrentamientos son ilegítimos: Judas reprende a sus hermanos Simeón y Jonatás por su rivalidad amorosa de pretendientes de Zarés:

Pues cuando Jerusalén
ofrece a vuestras espadas
de sus tiranos los cuellos
¿cómo podréis ofendellos
de vuestra sangre manchadas?
¿Qué injusta causa os obliga?
¿Qué tirana envidia lucha
en vuestros pechos? (pp. 341-342)

Es decir: la violencia obediente a los mandatos de Dios no engendra en este caso nuevas variedades de violencias, sino que reclama la exclusividad y prohíbe otras disensiones internas.

La violencia del general enemigo Lisías es completamente distinta a la de Judas. Desatinado por la pasión que siente por Zarés, obnubilado por su propia soberbia y brutalidad — se compara con los Gigantes que desafiaron a los dioses - pierde el dominio de sí y ve su autoridad discutida por sus capitanes. Su derrota será total, en medio de un cataclismo en el que el sol incendia al mundo, el viento se altera, la tierra se quiebra en terremotos y «todo es ciega confusión, / todo gri-

${ }^{3}$ Las indicaciones de páginas o versos corresponden a las ediciones citadas en la bibliografia. 
ta lastimosa» (p. 376), antes de la restauración de la ciudad santa de Jerusalén que cierra el ciclo.

En la guerra justa la violencia se somete a ciertos procedimientos de control. El sitio de Bredá pertenece a una guerra contra la herejía (p. 985: «porque el piadoso celo / desta divina hazaña / dé triunfos a la fe, glorias al cielo, / opinión a Felipo y honra a España), y aunque participa de las violencias habituales (p. 976: «Todo es iras el desierto, / toda es rayos la campaña, / toda es portentos la tierra, / todo es el cielo venganzas») el objetivo no es destruir al enemigo, sino convertirlo. Más noble es la victoria cuanto cuesta menos sangre, afirma don Luis, y el paralelo evidente con el tema de Numancia ${ }^{4}$ se estructura como negación antitética y no como asimilación:

\section{¿Es Bredá acaso Numancia? ¿Pretende tan necia gloria? (p. 1026)}

En la rendición el vencedor muestra su generosidad, y la especie de comedia celebrativa de un triunfo militar que proclama la nobleza de los españoles integra abundantes motivos de la cortesía: en los intervalos de los ataques, los sitiadores galantean a las damas de la ciudad, reflejando episodios reales, afirma Alonso Ladrón, defendiendo la verosimilitud de los mismos, que pudiera parecer extraña a algún espectador demasiado crítico. Esas escenas de El sitio de Bredá carecerían de sentido en la tragedia cervantina, pero no en una pieza optimista concebida como triunfal exaltación de la nobleza, valor y justicia de las tropas españolas.

Otra guerra santa es la que lleva a los portugueses acaudillados por don Fernando al asalto de Tánger en El príncipe constante. Las violencias de la guerra sirven para probar la constancia del héroe y mártir que elige la esclavitud y la muerte en defensa de la ley de Dios:

Por mi Dios y por mi ley

seré un príncipe constante

en la esclavitud de Fez. (p. 1113)

${ }^{4}$ Para la violencia en el caso de la Numancia cervantina ver Petro del Barrio, 2006, pp. 67 y ss. Para la comparación de Numancia y El sitio de Bredá, Arellano, 1999a. 
Si don Fernando responde a la violencia del cautiverio con la humildad estoica cristiana sublimadora en lo moral, otros personajes provocan la violencia generalizada en conflictos caóticos: las guerras entre pueblos distintos, o peor aún, las guerras civiles de La vida es sueño, La hija del aire, La gran Cenobia, El Tuzaní de la Alpujarra, El mayor monstruo del mundo, La cisma de Ingalaterra y otros dramas de Calderón, muestran la expansión de una violencia contagiosa que se extiende sin límites en batallas que no siempre tienen lugar entre ejércitos, sino que llegan hasta la desintegración de un mismo personaje desdoblado en personalidades enemigas que lo convierten en territorio de discordia perpetua.

Para detener esta epidemia hará falta un poder externo (el rey o juez que ponga fin a la escalada), o el autodominio de la violencia propia. Cuando no se den estas circunstancias la violencia persistirá como un horizonte de destrucción inacabable.

\title{
El contagio de la violencia
}

En La gran Cenobia los sucesos se desarrollan sobre el fondo de las guerras imperialistas de Roma contra Palmira, a las que se añaden las disensiones internas y los desórdenes que se multiplican en Roma y la corte de Cenobia: Aureliano asciende al poder tras la muerte sangrienta de Quintilio, depuesto por su propio ejército amotinado, y en Palmira los traidores Irene y Libio asesinan al rey Abdenato y provocan la derrota y prisión de la reina.

Aureliano, protagonista obsesionado por el poder y dominado por su «bárbara violencia» (v. 2351), despliega su terrible vocación desde el primer momento en el que es coronado en un intrincado bosque, corte de las fieras a las que convoca:

\author{
Salid fieras, salid de las oscuras \\ cárceles que os labraron peñas duras \\ y a mi coronación asistid, viendo \\ cómo mi honor pregono \\ cuando rey destos montes me corono. (vv. 58-63)
}

Toda la acción se construye como un tejido de violencias:Aureliano castiga arbitrariamente al general Decio, ataca el reino de Palmira, man- 
da despeñar a la profetisa Astrea, y al fin consigue derrotar a Cenobia, a la que pasea en triunfo humillante, aunque la ha vencido gracias a la traición de Libio (sobrino ambicioso y asesino del rey Abdenato). De la soberbia, la traición y la violencia nada cabe esperar: Aureliano morirá a manos de Decio, que se casa en el desenlace con Cenobia y ordena la ejecución de los traidores Libio y su amante Irene.

El inicio de la comedia (como en otras obras calderonianas) es esencial para fijar el tono y plantear los temas principales. Todo el primer discurso de Aureliano confirma esta caracterización: explica que huye de la ciudad empujado por la rabia y la envidia. Su obsesión patológica por reinar le produce una «mortal melancolía». El léxico inicial abunda en los motivos oníricos y de la fantasía desarreglada: «pálida imagen de mi fantasía", «fantasma de mi pensamiento", "ciego, oscuro abismo", etc.:

Aureliano

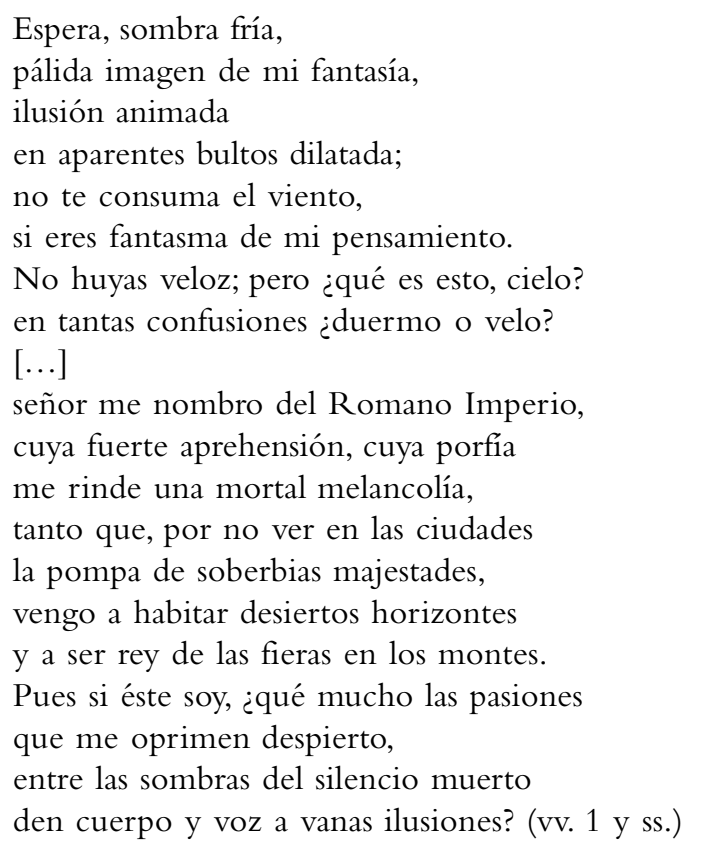

Si la trayectoria de Aureliano empieza entre visiones fantasmales y accesos de rabia, su final será semejante, muriendo frenético y enloquecido: 
Con mi mano arrancaré
pedazos del corazón
y en desdicha tan crüel,
para escupírsela al cielo
de mi sangre beberé:
que hidrópico soy y en ella
tengo de aplacar mi sed.
Rabiando estoy y contento,
Decio, de que no he de ver
tus aplausos. ¡Ay de mí! (vv. 2807-2816)

Desde el punto de vista del mecanismo violento, si Aureliano actúa con un egoísmo constitutivo, Decio mata al tirano en aras del bien común y la salvación de la patria, no por ambición personal. Su tiranicidio no significa un paso más en la espiral de la violencia, sino el límite que termina con ella, instaurando una etapa de orden. En cierta medida podrían aplicarse a Aureliano los conceptos que desarrolla Girard del chivo expiatorio o víctima sacrificial, la cual concentra en sí todas las violencias, las exaspera y al final las resuelve con su muerte o expulsión, pero en este caso la víctima expiatoria es completamente culpable y el debate trágico no es imparcial ni conduce a una reproducción inacabable ${ }^{5}$ : las sucesivas guerras entre Roma y Palmira se cierran con el pacífico matrimonio del nuevo emperador y de Cenobia.

Mucho más negativo es el desenlace de La cisma de Ingalaterra, coherente con la estructura global del drama, que enfrenta las pasiones $\mathrm{y}$ ambiciones de tres protagonistas principales (Enrique VIII, Ana Bolena y el cardenal Volseo), contrapuestas a la virtud de la reina Catalina. El rey, arrastrado por una pasión ilegítima, repudia a su mujer, rompe con la Iglesia y provoca el caos en su reino.Volseo, hijo de un infame carnicero, exaltado a la púrpura, ambicioso y orgulloso sin medida, acaba en desgracia y se suicida desesperado; Bolena termina su aventura en el cadalso, resultado de una ambición desbordada, mientras la reina muere en el destierro de la corte.

Aunque Calderón, por motivos de decoro dramático, ennoblece a Enrique VIII, su condición corresponde a la que con más agresividad

${ }^{5}$ Ver Girard, 1983 , pp. 50-55 para el mecanismo contagioso de la violencia y su reproducción. 
explícita se describe en la principal fuente histórica de la obra, la Historia eclesiástica del cisma del reino de Inglaterra, del P. Pedro de Rivadeneyra $^{6}$, donde se le compara con un "caballo desbocado y sin freno [que] corría tras todos los vicios y maldades, y principalmente tras la lujuria, avaricia y crueldad» ${ }^{7}$. Los agentes de la violencia contaminan el reino entero, que se desintegra en cisma religioso, político y personal: la deslealtad y la traición, las «sediciones y alborotos» (v. 1984), la muerte y la guerra civil se enseñorean de todo:

y será con civil guerra
asombro de Ingalaterra
el hijo del carnicero. (vv. 704-706)

El rey califica a su lucha interior como "confusa guerra» (v. 1627) que oscurece su razón ${ }^{8}$ : al final hace que los nobles juren a su hija María con ciertas condiciones y esta acepta la corona decidida a no respetar tales condiciones: desenlace que significa un horizonte de guerras intestinas y destrucción. La cisma verdadera aún no ha empezado cuando la comedia termina.

Como se ve Calderón ofrece distintas posibilidades y soluciones (o faltas de soluciones) en su exploración de los procesos de la violencia. El reflejado en Amar después de la muerte culmina en un desenlace más ambiguo que en los dos casos anteriores, pero cercano al conflictivo de La cisma.

La tensa convivencia de cristianos y moriscos no se resuelve en armonía e integración, sino que estalla en un conflicto violento con características de guerra civil, pues los moriscos se reconocen españoles. Se presenta como detonante la promulgación de las ordenanzas reales de 1567, y la brusquedad con que se ponen en práctica, denunciada en las palabras de don Juan Malec:

${ }^{6}$ Ver Escudero, 2001, pp. 25-39.

${ }^{7}$ Volveré después sobre este tipo de imágenes emblemáticas de la violencia, como el caballo desbocado, un motivo frecuente en Calderón.

${ }^{8}$ Con una imagen parecida referida explícitamente a la idea de la cisma expresa Semíramis su turbulencia anímica al quedar retirada del poder que conquistará de nuevo por la violencia: La hija del aire (segunda parte), vv. 2086-2087: «Yo, pues, no quepo en mí, y con nueva cisma / solicito explayarme de mí misma». 
dije que aunque era

ley justa y prevención santa ir haciendo poco a poco de la costumbre africana olvido, no era razón que fuese con furia tanta y así que se procediese en el caso con templanza porque la violencia sobra donde la costumbre falta. (vv. 104-113)

Pero no son esas leyes las únicas causas: es evidente que consagran una situación de hecho marcada por la violencia larvada que se puede revelar en cualquier momento. Baste recordar la conducta de don Juan de Mendoza, que agravia al viejo Malec despreciando su raza y pegándole con su propio báculo, deshonrándolo en suma, y obligándolo a la venganza (vv. 117 y ss.). Rotos los frenos, el contagio se extiende imparable. Antes del motín y la consiguiente represión una epidemia de irracionalidad parece dominar a todos los personajes: doña Clara, hija de Malec, acepta casarse con el ofensor de su padre para vengarse de él; matrimonio absurdo propuesto por don Fernando Valor, noble morisco que encabezará después la rebelión haciéndose nombrar rey de la Alpujarra con el nombre de Abenhumeya. La atmósfera conflictiva se enrarece por las relaciones internas: de Clara está enamorado don Álvaro Tuzaní, cuya hermana Isabel es cortejada por don Juan de Mendoza, quien como hemos visto, desprecia a los moriscos, lo que hace suponer en él intenciones no muy legítimas acerca de sus relaciones con Isabel, a quien afectarían las mismas razones que esgrime para negarse al matrimonio propuesto con Clara:

ni sé que fuera decente
mezclar Mendozas con sangre
de Malec, pues no convienen
ni hacen buena consonancia
los Mendozas y Maleques. (vv. 818-822).

En semejantes circunstancias, la serie de ofensas y represalias generalizan la violencia y toda la Alpujarra se pone en armas: 


\author{
ya civiles bandos hecha \\ unos «España» apellidan, \\ otros «África» vocean \\ de suerte que su mayor \\ ruina, que su mayor guerra \\ hoy parciales y divisos \\ tienen dentro de sus puertas. (vv. 2763-2769)
}

Dentro del caos múltiple destaca la historia concreta del asesinato brutal de Clara Maleca por el soldado Garcés y la venganza de don Álvaro Tuzaní. No hay duda de la culpabilidad del codicioso soldado asesino, pero son significativas algunas palabras suyas, que podemos interpretar como expresión de la cualidad mimética de la violencia: enajenado por una especie de locura (la locura contagiosa de la violencia global) mata a Clara «arrebatado no sé / de qué furia, de qué saña / que me movió el brazo entonces» (vv. 3076-3078). Garcés concentra dramáticamente la violencia universal, convertido en un agente cuya acción individual se difumina en la de la masa: su muerte funciona como mecanismo exutorio de la violencia de la multitud, lo mismo que la muerte de Abenhumeya a manos de sus propios súbditos amotinados lo convierte en una víctima expiatoria que permite el perdón para los rebeldes. Don Juan de Austria perdona también al Tuzaní, pero es dudoso que la paz alcanzada sea estable: cimentada en un esquema de agravios y represiones, sometidos por la fuerza los rebeldes, nada se dice de la futura convivencia, cuyo fracaso, en efecto, se confirmará en la historia posterior a los hechos dramatizados, al firmar Felipe III en 1609 la expulsión definitiva de los moriscos.

El contagio de la violencia impregna todos los niveles de la sociedad y del individuo, sin especializarse en los conflictos políticos.

La devoción de la cruz es un ejemplo de crisis familiar ${ }^{9}$ enraizado en la violencia patológica de Lisardo Curcio, padre inhumano y verdugo de su familia.

Hallamos en esta obra fratricidio, apunte de incesto, linchamiento y uxoricidio. Todos los sucesos arrancan de un crimen previo: Curcio, por infundadas sospechas, intenta matar a su esposa al pie de una cruz,

${ }^{9}$ La supuesta proyección de la historia familiar de Calderón en esta comedia (ver Delgado, 2000, pp. 26-27) me parece muy injustificada: ninguna prueba real permite tal inferencia, ningún crítico aduce datos fehacientes. Y desde el punto de vista de la 
desapareciendo ella milagrosamente y dando a luz a dos criaturas, Julia, y un niño, Eusebio, que quedó perdido en el bosque. La trama conducirá al reconocimiento de los hermanos, en una escena final de sublimación religiosa en la que se muestra el poder de la cruz para asegurar la salvación a los que no pierden su fe en ella.

Pero Curcio se opone siempre a la misericordia de la cruz. En él tiene principio la tragedia al empeñarse en matar a su mujer por fútiles sospechas. El parecido con don Gutierre de El médico de su honra que algunos estudiosos ${ }^{10}$ han visto es, a mi juicio, inexistente. Curcio se inventa los motivos para su asesinato, motivos que él mismo reconoce falsos, confesando la inocencia de su esposa Rosmira ("confesando que fue casta / tomé de mis pensamientos / no de sus culpas venganza", comp. vv. 699-706, 1300, 1323, 1353...).

Curcio, como otros maridos calderonianos, se lamenta de que el imperativo del honor le obligue a tomar una decisión cruel (vv. 672 y ss.), pero es su propia violencia la que le mueve (pues no hay motivos para sospechar de su mujer: solo un parto al octavo mes, cosa bastante normal). Por el contrario don Gutierre, como veremos después, no se inventa las razones que le obligan a vengar su honor: esas razones existen.

La violencia de Curcio es como un veneno que inficiona todo lo que toca: por su abandono Eusebio se hace un ser salvaje; por su opresión la vida de Julia se corrompe; en su imitación Lisardo se enfrenta brutalmente a Eusebio (que lo mata sin saber que es también su hermano) y se refiere a Julia con palabras iguales a las que usa su padre («mañana ha de ser monja / por voluntad o por fuerza» dice Lisardo, vv. 185-186; «que sola mi voluntad / en lo justo o en lo injusto / has de tener por tu gusto", dice Curcio, vv. 583-585). La reivindicación de la libertad de la hija para escoger su estado («que el hado impío / no fuerza el libre albedrío», vv. 588-589) enfurece al padre:

violencia en el teatro calderoniano La devoción de la cruz se inserta perfectamente en la exploración sistemática de dichos mecanismos: no constituye ninguna excepción para cuyo entendimiento haya que apelar a la biografia del poeta (cosa que por otra parte se ha intentado también con La vida es sueño, por ejemplo, con la misma falta de justificación).

${ }^{10}$ Comp. Delgado, 2000, p. 31: «Curcio se convierte en un médico semejante a don Gutierre». Ver el comentario de El médico de su honra más abajo. 


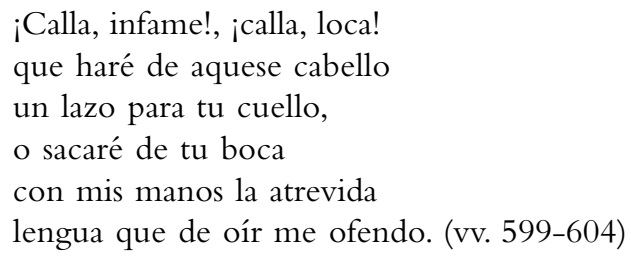

Para este tenebroso tirano solo existe su voluntad, que no reconoce libertad ni derecho alguno a los otros. La contaminación es total: desde su infancia la vida de Eusebio es un rosario de violencias, a menudo ocasión milagrosa para que la cruz muestre su poder: su ama, airada por una mordedura feroz del niño, lo tira a un pozo; sufre naufragio en una tormenta; se salva de unos bandoleros; se libra de una estocada casi mortal; lo mismo de un rayo... en todos los casos debe a la cruz su salvación. Convertido en bandolero se sustenta matando y robando, asalta el convento de su hermana, viola todo lo humano y lo divino. No hará menos Julia cuando se entregue desesperada a la perdición: mata a un pastor, a un caminante, a un matrimonio que la acoge, a un cazador (vv. 1940 y ss.) con tal audacia que asusta al mismo Eusebio.

El desenlace reproduce el momento de la violencia original: Eusebio, linchado por la multitud, muere al pie de la misma cruz en que Curcio atacó a Rosmira; allí acude Julia pidiendo la ayuda de la cruz divina. Curcio, a pesar de los sucesos trágicos y milagrosos que ha presenciado (el alma de Eusebio se ha detenido en su cadáver hasta que el sacerdote Alberto puede confesarlo), no ha aprendido nada: amenaza a su hija con matarla, como hizo con su mujer:

\author{
¡Oh, asombro de las maldades! \\ Con mis propias manos hoy \\ te mataré, porque sean \\ tu vida y tu muerte atroz. (vv. 2566-2569)
}

Pero ella asciende asida a la cruz del sepulcro de Eusebio, eludiendo la violencia paterna, para regresar al convento y «hacer nueva vida» de conversión. Esta solución final (salvación por la cruz) no elimina la tragedia humana que ha sucedido en el mundo: la cruz salva a Eusebio y Julia de la muerte espiritual, pero no de sus sufrimientos en vida. 
No hará falta demorarse mucho en una de las piezas más conocidas de Calderón, El alcalde de Zalamea, para examinar la acumulación de violencias que define, de nuevo, la trama. La llegada de las tropas a Zalamea desencadena una escalada que parece irrefrenable. Los primeros enfrentamientos entre Juan y el capitán los corta la autoridad de don Lope de Figueroa, pero el capitán sigue empeñado en su pasión, que describe en términos de irracionalidad:

Este fuego, esta pasión, no es amor sólo, que es tema, es ira, es rabia, es furor. (vv. 935-937)

Con la pelea nocturna en la desvergonzada serenata que los soldados cantan a Isabel se pone de manifiesto la degradación de las tensiones, la falta de respeto de don Álvaro a su general, el desprecio por los villanos. El capitán ha puesto en marcha la división violenta de la comunidad:

huésped ingrato, que el día

primero introdujo en casa

tan nunca esperada cisma

de traiciones y cautelas,

de pendencias y rencillas. (vv. 1911-1915)

El secuestro y violación de Isabel culminan la primera fase de este despliegue. El castigo del violador, que está a punto de provocar la destrucción de Zalamea por el ejército, es el núcleo de la segunda fase de reacción. La llegada del rey impide el ataque de los soldados. Se necesita este juez supremo, que legitima el procedimiento jurídico de Crespo, para cesar la espiral de violencia que los demás no podrían detener: don Lope se cree obligado a defender los fueros militares y Crespo ha demostrado su capacidad mimética (jura con quien jura, reza con quien reza ${ }^{11}$ para caer también en el proceso de la violencia, por defender en este caso su dignidad básica de ser humano. No exactamente su honor, como dice él, probablemente porque el vocabulario del honor es el más se acerca a lo que quiere expresar. La

11 Para esta capacidad mimética de Crespo, importante para la captación del personaje ver Vitse, 1988, p. 290. 
cuestión merece unas palabras, aunque es demasiado compleja como para tratarla en detalle.

A pesar de la declaración - cuya perfección verbal ha ocultado a menudo su sentido- tan repetida de Crespo (vv. 873-876: «al rey, la hacienda y la vida / se ha de dar; pero el honor / es patrimonio del alma, / y el alma sólo es de Dios»), lo cierto es que el honor "del alma» no ha sido destruido por la vejación de la inocente Isabel. En el comienzo de La ciudad de Dios, y a propósito de las vírgenes cristianas violadas por los bárbaros aclara San Agustín que en nada estorba a la castidad y la pureza de estas doncellas la violencia de que han sido víctimas. El alma queda incólume, y lo que en realidad ha sido dañado es el honor social, daño que frustra el horizonte vital de Isabel y la lleva a la clausura del convento.

En esta y en todas las ocasiones que podamos aducir Crespo adopta el sistema de valores que incluye el concepto nobiliario del honor, el cual respeta tanto que no quiere comprar una ejecutoria porque no le daría nobleza sino solo apariencia de noble, simulando lo que no es, confundiendo nobles y villanos, y erosionando por tanto la estructura social (volveré sobre esto a propósito del honor y la violencia), estructura que nunca cuestiona Crespo ${ }^{12}$.

Isabel va al convento porque ha sido "deshonrada» y nadie se casará con ella. No creo que aquí acierte Bandera ${ }^{13}$ al oponer radicalmente el concepto del honor de Crespo con el de don Gutierre, considerando el de aquel un don de Dios que requiere la renuncia a la otra clase de honor (social, de opinión). Curiosamente Bandera explica muy bien el grado de esclavización — que mide la subordinación al código honroso- al que está dispuesto a llegar Pedro Crespo cuando ruega de rodillas al orgulloso capitán, pero concluye que

12 Esta circunstancia a mi juicio le da a Crespo una dimensión humana más profunda y emotiva que si fuera, como algunos han visto, un rebelde contra el sistema. Acepta la organización social, pero exige el respeto que como ser humano le corresponde, esté donde esté (es decir, exige el respeto a todos los hombres en cuanto a su igualdad fundamental, no social): por eso se siente justificado en castigar a ese capitán que se entró en su honor «sin ser jurisdicción suya». Le servirá con su casa y hacienda, pero no tolerará que se anule su derecho en aquel terreno que le pertenece.

13 Bandera, 1997, p. 172, página a la que corresponde la cita inmediata. 
la renuncia voluntaria y generosa de Pedro Crespo de todo lo que puede ser percibido exteriormente salva su valía interna, ese don de Dios, como había dicho él, de la esclavitud al otro, mientras que los maridos asesinos consiguen preservar una apariencia bastante precaria a expensas de su pérdida interior de libertad.

¿Cuál es valía interna que conserva Crespo? Me parece que la esclavización a la que se somete solo podría salvarse en esa dimensión «interior» por la generosidad que supone al ofrecerla voluntariamente en beneficio de otro. Pero si comparamos este caso con la esclavización voluntaria de don Fernando en El príncipe constante se advertirán diferencias sustanciales: don Fernando ofrece su libertad en defensa de la fe y para preservar la religión cristiana en Ceuta. Crespo ofrece esclavizarse para salvar el honor de Isabel, que sería reparado si el capitán se casa con ella: Crespo en suma, está dispuesto a entregar su libertad y su persona a cambio de que se repare el honor (entendámonos, el honor social, el honor opinión, no el del alma) de su hija, código, por tanto, al que se supedita del mismo modo que se supedita don Gutierre (o peor aún, porque esa supeditación es, paradójicamente, un mimetismo nobiliario).

Ahora bien: el resultado de situaciones semejantes en los dramas de honor conyugal era la muerte de la mujer (inocente o no). La propia Isabel — aceptando sin reparos el mismo código social - incita a su padre:

Tu hija soy, sin honra estoy,

y tú, libre; solicita

con mi muerte tu alabanza,

para que de ti se diga

que por dar vida a tu honor

diste la muerte a tu hija. (vv. 2062-2067)

Es precisamente lo que Juan, el hermano de Isabel, se dispone a hacer. Crespo detiene esta solución trágica mortal para elegir una variante más suavizada, limitándose a sufrir las consecuencias del código del honor, pero sin sobreponerlo de manera absoluta al amor paterno y a su concepto de justicia: mata al ofensor, pero no a la inocente.

El rey llega a tiempo de cortar la progresión de la violencia, pero no puede evitar los daños en las víctimas. Crespo queda alcalde per- 
petuo, pero solo, con la familia destruida, Isabel en el convento, y todo el pueblo ${ }^{14}$ comentando (unos compasivos, otros maliciosos) esta triste historia del famoso alcalde de Zalamea.

La escena que con más violencia debió de impresionar al atónito espectador del Siglo de Oro - un hijo que golpea a su padre- se encuentra precisamente en la pieza calderoniana de Las tres justicias en una ${ }^{15}$ :

Don Lope hijo Toma, caduco.

Da un bofetón a su padre, que cae al suelo.

VICENTE

¿Qué has hecho?

Don Lope padre ¡Caiga el cielo sobre ti!

A él hago testigo yo que es su causa la primera.

Gente

Todos te ayudamos. ¡Muera el que a su padre ofendió! (p. 697)

Este don Lope hijo es un joven violento, bandolero y asesino. En la investigación del escándalo que el rey ordena a don Mendo, se descubre que don Lope es en realidad hijo de don Mendo y de una hermana de Blanca, la supuesta madre de Lope, que fingió haberlo dado a luz para evitar la deshonra de la hermana. En cualquier caso el rey ordena que ajusticien a don Lope, que ha infamado a quien tenía por padre.

En este drama el fracaso violento afecta a todos los personajes principales en un mecanismo ya observado de expansión generalizada de

${ }^{14}$ En ese «corto lugar» donde donde «otra falta no tenemos / más que decir unos de otros / las faltas y los defetos» (vv. 2232-2235) la suerte del alcalde está echada. Será ya siempre una figura ambigua cuyo respeto navegará sobresaltado en las turbulencias de hablillas, fábulas y murmuraciones.

15 Bances Candamo en su Teatro de los teatros (p. 35) dice que Calderón deseó mucho recoger esta comedia (por confusión le atribuye el título De un castigo tres venganzas) por el horror que daba el escandaloso caso. Duncan Moir (1970, pp. LXXXIIILXXXIV) supone que la escena "debió de horrorizar al público del siglo XVI», con lo que estoy de acuerdo. Menos certera me parece su opinión de que es un «ejemplo de violencia particularmente repugnante el cual es muy raro en el teatro de Calderón». Por lo que se va viendo ninguna categoría de violencia es rara ni ajena al teatro calderoniano. 
culpas y consecuencias nefastas: don Mendo, por abandonar a su amante y su hijo nonato, lo ve al final ajusticiado; don Lope padre sigue creyendo que el ajusticiado es su hijo —otra fuente de infamia para el mismo don Lope-, al que nunca ha querido con amor paternal; la madre adoptiva (tía en realidad), que engañó —aunque con buena intención - sufre igualmente el dolor de la catástrofe... Y la principal víctima, don Lope hijo, paga por los pecados propios y por los ajenos, como una víctima expiatoria cuya muerte, sin embargo, no es capaz de instaurar una nueva etapa de renovación. Desde esta perspectiva no funciona en este - como no funciona en otros dramas de Calderón - la eficacia del rito sacrificial que analiza Girard en La violencia y lo sagrado. Más bien la obra de Calderón pertenecería, como la Biblia-según la aproximación girardiana-, a la categoría de instrumentos desmitificadores de la violencia sagrada primitiva, cuya arbitrariedad y radical injusticia ponen de manifiesto ${ }^{16}$. El sacrificio de don Lope es un castigo merecido, pero no sirve para exculpar a los demás ni para ocultar las responsabilidades contraídas por cada uno. En Las tres justicias en una nadie — esposos, padres, hijos- quiere a nadie, todos se abisman en sus propios egoísmos y se relacionan por el odio y la frustración: por ese camino, parece enseñar Calderón, no se puede evitar la crisis de la violencia.

Del ámbito de la guerra internacional o civil, al campo más reducido - en extensión, que no en intensidad- de las relaciones familiares campea, pues, la violencia, siempre cambiante pero siempre la misma.

A veces se produce una mezcla de ambos territorios, el político y el individual, y la violencia se multiplica todavía más. Excelentes oportunidades para analizar estas mezclas, más caóticas, si cabe, que las ya comentadas, dan comedias como El mayor monstruo del mundo, La vida es sueño o Los cabellos de Absalón.

A la primera he dedicado ya algunas páginas a las que remito para mayores comentarios. Solo apuntaré ahora que la racionalidad, sere-

16 Creo en este sentido que el análisis de Petro del Barrio (2006) no tiene suficientemente en cuenta el ámbito cristiano de la comedia española del siglo XVII en su aplicación de las teorías de Girard. Al menos en el caso de Calderón los rituales sacrificiales no son capaces de legitimar ninguna violencia: o fracasan o son denunciados como una falsificación. 
nidad y cualidad heroica que muchos críticos han visto en el protagonista Herodes es otra ilusión postromántica que no se puede sostener a la vista del texto calderoniano ${ }^{17}$. En el marco de las indagaciones sistemáticas sobre la violencia que definen en buena parte el mundo de sus dramas me parece evidente que la cólera y lo irrefrenable de los excesos pasionales de Herodes apartan radicalmente a este personaje del modelo de varón estoico al que le asimilan algunos estudios: véase su colérica reacción con Filipo y Tolomeo (vv. 3194 y ss.), o antes, el intento de asesinar a Octaviano, etc., hasta que acaba matando a su mujer y suicidándose.

Examinado sobre el modelo de príncipe perfecto aurisecular que proponen los tratadistas del ars gubernandi, y contraponiéndolo a su antagonista Octaviano, se percibe meridianamente que este Herodes es un gobernante pésimo, catalizador y transmisor del desorden, dominado por una pasión - los celos- a la que define en el inequívoco lenguaje de la violencia extrema:

Pues si los celos difinir hubiera,
en un camaleón los retratara
que del aire no más se alimentara
y a cada luz nuevo color tuviera.
Ojos de basilisco le pusiera
que con ser visto o ver siempre matara,
pies de topo que en todo tropezara
y alas de halcón, que todo lo cogiera.
De la sirena le añadiera el canto,
del áspid las cautelas, los desvelos
del lince, y de la hiena, en fin, el llanto.
Mas ¿dónde vas? Parad, parad, recelos,
no forméis un compuesto de horror tanto
que el mayor monstruo hayan de ser los celos.

(vv. 3065-3082)

Desde la perspectiva que ahora me interesa - la violencia-, tampoco escapa nadie en La vida es sueño. Clotaldo abandona a la madre de su hija y a la misma Rosaura, a la cual abandona Astolfo en una

${ }^{17}$ Arellano, 1999b. Allí recojo la bibliografia pertinente para la discusión del carácter del Tetrarca. 
reproducción — parcial- del engaño; Rosaura pretende vengar su honra a filo de espada (vv. 373-377); y no hay que ponderar la violencia a la que está sometido Segismundo, ni la que él despliega en su conducta. Tratado como un monstruo, reacciona como tal:

aquí, porque más te asombres

y monstruo humano me nombres, entre asombros y quimeras

soy un hombre de las fieras

y una fiera de los hombres... (vv. 208-212)

Se suceden sin tregua escenas de cóleras, agresiones, intentos de violación, defenestraciones, prisiones y muertes, rebeliones y por fin una guerra civil que resume el caos general:

Si tu presencia, gran señor, no trata de enfrenar el tumulto sucedido, que de uno en otro bando se dilata por las calles y plazas dividido, verás tu reino en ondas de escarlata nadar entre la púrpura teñido de su sangre; que ya con triste modo, todo es desdichas y tragedias todo.

Tanta es la ruina de tu imperio, tanta la fuerza del rigor duro y sangriento, que visto admira y escuchado espanta. El sol se turba y se embaraza el viento; cada piedra un pirámide levanta y cada flor construye un monumento; cada edificio es un sepulcro altivo, cada soldado un esqueleto vivo. (vv. 2460-2475)

No analizaré los orígenes ni las responsabilidades de esa situación (fundamentalmente el error de Basilio, acompañado de los de otros personajes que contribuyen a la expansión de la violencia, entre ellos Segismundo en una primera etapa de su comportamiento, anterior a lo que se ha llamado su conversión), pero me interesa contemplar de nuevo el desenlace del drama, esencial para la interpretación de las dimensiones de la violencia en esta obra. 
Hay dos posibilidades básicas de interpretación ${ }^{18}$ : la de quienes piensan que Segismundo continúa los procedimientos de su padre y por tanto la violencia y destrucción serán incesantes, y la de quienes entienden el final como una superación del desorden y la violencia por parte de un Segismundo justo que instaura una nueva época.

Los primeros consideran que en el tercer acto Segismundo asimila los métodos de su padre en un proceso de «basilización» (en términos de Vittorio Bodini ${ }^{19}$ ) que sigue manteniendo el mismo sistema que él había denunciado previamente... Para Bandera, que aduce el episodio del soldado rebelde, aceptando interpretaciones como las de Hall20, el final de La vida es sueño tiene resonancias siniestras y evidencia «la profunda igualdad entre padre e hijo». Vitse en cambio ${ }^{21}$ acepta la evolución positiva de Segimundo, interpretándola como una victoria de la nueva generación sobre los fracasos de las instancias paternas. A mi juicio la solución coherente es la positiva, única compatible con la obvia desautorización de Basilio y la denuncia de sus errores. La violencia puede ser dominada por el libre albedrío, el control de sí mismo y la justicia ${ }^{22}$.

Otro padre y rey que fracasa es David en Los cabellos de Absalón. En este caso la estructura de la comedia no responde a una trayectoria superadora, sino que se concentra en la expresión de la misma violencia, desnudando los impulsos — sexo, poder, rivalidad, envidia, venganza, complejo de culpa...- que dominan a los personajes.

El príncipe Amón se halla preso de fúnebre melancolía provocada por la pasión culpable que siente hacia su hermana Tamar, pasión fatal y posesiva que causa temor al mismo Amón. Por su parte Absalón

${ }^{18}$ Ver para un repaso de la crítica más reciente sobre la comedia, incluido el problema del final Antonucci, 2008.

19 Bodini, 1968.

${ }^{20}$ Bandera, 1975, pp. 257-259. Comp. Hall, 1968. El episodio ha dado lugar a numerosa bibliografía que no hace ahora al caso.

${ }^{21}$ Ver Vitse, 1980.

${ }^{22}$ He comentado este desenlace en Arellano, 2001, pp. 78-79: «Segismundo no acepta el juego para conservar su status: podía haber vejado a su padre, castigado a Clotaldo; podía haberse quedado con Rosaura... Lo que hay en el desenlace es un sufrimiento aceptado, una renuncia consciente de impulsos pasionales que son indignos de la figura del rey - de nuevo es preciso acudir a la idea del monarca en el Siglo de Oro- - Hay, en suma, un triunfo de la libertad y la voluntad humana sobre los apetitos y sobre los horóscopos». 
está a su vez enajenado por la ambición, el ansia de dominio y la vanidad de su belleza simbolizada por sus hermosos cabellos. El ambiente de la corte real se carga de aciagos presagios que formula en tono profético Teuca, y todo augura la catástrofe, ligada a la maldición divina y a la expiación de los pecados de David y de los restantes personajes. Todos se hallan desgarrados internamente y entre sí.Violación — de Tamar y las concubinas de David-, fratricidio, intento de parricidio - y magnicidio-, guerra, suicidio y asesinato... son de nuevo los elementos que componen este desorden universal. Amón se odia a sí mismo y se siente dividido, manejado por otro - una parte ajena de sí mismo- que lo arrastra donde no quiere ir (p. 832); Teuca está poseída por un espíritu diabólico «de odio y de ira / de rencor y discordia» (p. 854); David está dilacerado entre el amor paterno y la obligación de rey, sin cumplir esta y contribuyendo por tanto a la catástrofe; Absalón hace la guerra a sangre y fuego «a mi padre y mis hermanos» (p. 854); Tamar, vengativa, quiere derribar a sangre y fuego las almenas de Jerusalén (p. 856)... Todo constituye, en palabras de Salomón, un «escándalo de horror fiero» (p. 857).

El triunfo de la facción de David, tras la muerte de Absalón colgado de sus cabellos y alanceado por Joab, no se celebra con alegres salvas, como en el comienzo del drama se celebraba el regreso victorioso del rey tras la conquista de Rábata - guerra santa esta contra el filistín-, sino con roncos y tristes acentos, volviendo David a Jerusalén «más que vencedor vencido" (p. 864). Su debilidad, y su complejo de culpa por la prehistoria de Urías y Betsabé, ha impedido al rey detener la violencia que ha destruido su familia y casi al reino entero.

\section{El honor y la violencia}

En este mundo de conflictos hay un territorio bien definido donde la violencia domina, en efecto, como reina de todas las cosas, según decía Heráclito: el universo del honor tal como se manifiesta en las tres piezas claves El pintor de su deshonra, $A$ secreto agravio secreta venganza y El médico de su honra.

No es posible examinar aquí en detalle todas las complejidades que presenta el tema del honor en las comedias de Calderón ni los recovecos de los procesos victimarios que involucran no solo a las mujeres, como se suele afirmar, sino también - y principalmente- a los 
maridos. Me limitaré a algunos apuntamientos en torno al papel de la violencia en este universo.

Son innumerables los comentarios sobre el problema del honor en la comedia del Siglo de Oro, y hay en ellos todo tipo de interpretaciones. Uno reciente de Antonia Petro del Barrio ${ }^{23}$, lo examina precisamente en el marco de la legitimación de la violencia, sosteniendo que la ritualización de las muertes como la de doña Mencía en El médico de su honra sirven para sacralizar el asesinato, justificándolo desde el punto de vista del homicida, convirtiéndolo en algo más que una venganza personal.

$\mathrm{Al}$ interpretar estas muertes sobre las teorías antropológicas del rito sacrificial halla la dificultad del secreto ( $A$ secreto agravio secreta vengan$z a)$, ya que el ritual victimario exige la participación de toda la comunidad, mientras que los maridos calderonianos procuran mantener el máximo secreto posible.

Petro del Barrio está sin duda en lo cierto — cosa bien sabida - al indicar que el honor no es cuestión individual sino que afecta a toda la estructura social, circunstancia que hace aún más difícil — añadoexplicar que la comunidad no participe en el supuesto ritual.

Creo que la dificultad surge de la incompleta identificación de la víctima. A mi juicio la víctima propiciatoria sobre la que gravita la responsabilidad de mantener el orden social es doble: no solo la mujer muerta sino sobre todo el marido uxoricida, que debe actuar presionado por el código del honor-opinión, código social mantenido por el conjunto de la comunidad, que en este sentido participa plenamente como fuerza constrictora de la que no puede evadirse el marido honrado. Las quejas reiteradas de los maridos ${ }^{24}$ por esta obligación terrible en la que se ven evidencian tanto su cualidad victimaria como la erosión de la unanimidad sacrificial que es requisito necesario para el eficaz funcionamiento de la violencia. Las mujeres son, por así decirlo, víctimas secundarias en este esquema. Bandera ha

23 Petro del Barrio, 2006.

${ }^{24}$ Ver por ejemplo la de don Juan Roca en El pintor de su deshonra, p. 897: «¿Mi fama ha de ser honrosa, / cómplice al mal y no al bien? / ¡Mal haya el primero, amén, / que hizo ley tan rigurosa! /¿El honor que nace mío, / esclavo de otro? Eso no. /¡Y que me condene yo / por el ajeno albedrío! / ¿Cómo bárbaro consiente / el mundo este infame rito?». 
planteado bien la situación, pero no llega, creo, a las últimas consecuencias:

La ley del honor exige una víctima y el marido no tiene opción; o debe tomar él mismo el lugar de la víctima [...] condenado al más completo ostracismo y sujeto al desprecio público, o debe encontrar una víctima sustitutoria sobre cuyos hombros pueda poner la carga de su propia deshonra. Y es que, sin duda alguna, la esposa no es asesinada como castigo por lo que ha hecho o lo que se cree que ha hecho, sino únicamente como depositaria de la deshonra del esposo ${ }^{25}$.

En mi opinión el marido no escapa a su condición de víctima por el hecho de matar a su mujer: esa situación trágica es suficientemente destructiva, lo constituye realmente en víctima. La mujer no es una víctima totalmente sustitutoria: es lo más cerca que tiene el marido, forma con él una unidad. Matar a la mujer es asumir también el sacrificio propio.

Es interesante observar que muchos críticos que señalan la insoportable presión del código del honor sobre el marido y explican perfectamente la tragedia de la presión social, arrastrados después por el horror de la situación, condenan a los homicidas - especialmente a don Gutierre de El médico de su honra ${ }^{26}$ _ juzgándolos monstruos irracionales y enfermos obsesivos, como si se inventaran de la nada los motivos para matar a las mujeres ${ }^{27}$.

25 Cit. por Petro del Barrio, 2006, p. 39. En efecto, el marido que no cumple los requisitos del código es expulsado de su comunidad, privado de la única atmósfera en la que puede sobrevivir como tal caballero, con su identidad y personalidad. En A secreto agravio, don Juan Roca, cuya deshonra ha sido notoria, ha de vagar por el mundo, disfrazado de pintor, con identidad falsa hasta que la muerte de Serafina y don Álvaro, lavando su deshonra con sangre, le permitan adoptar de nuevo su nombre y personalidad.

${ }^{26}$ Ver Armendáriz, 2007 para una completa documentación sobre el panorama crítico en torno a El médico de su honra y su protagonista. A don Gutierre se le ha insultado con todos los calificativos posibles. Pocas voces (entre ellas especialmente brillante la de Vitse, 1997 y 2002) han abordado la justificación de la conducta de este personaje. Podría decirse que la casi unanimidad violenta de la comunidad estudiosa contra don Gutierre confirma de modo indirecto su calidad de víctima expiatoria.

27 No hace falta decir — aunque lo apunto por si acaso- que al hablar de motivos para matar a las mujeres me refiero estrictamente a los sucesos de la trama, y no a ningún tipo de justificación moral del sistema... 
Pero el hecho cierto es que de las tres mujeres involucradas en los dramas que contemplo solo Serafina de El pintor de su deshonra es inocente, mientras que la culpabilidad ${ }^{28}$ de Leonor en $A$ secreto agravio es tan evidente que la venganza de don Lope ha merecido menos condenas que la de don Gutierre. Detengámonos un momento en este último caso de El médico de su honra.

Petro del Barrio ${ }^{29}$ afirma, por ejemplo, que Mencía es inocente, y solo aparece culpable ante la opinión de su esposo, el cual se basa en «pistas que cree encontrar en el mundo real». Cesáreo Bandera ${ }^{30}$ también considera completamente inocente a la esposa muerta ante la mera sospecha de infidelidad, por causa de «una apariencia». Para Marshall ${ }^{31}$ don Gutierre es un verdugo de conducta aborrecible que va en busca de una enfermedad que no existe.

Dos cosas pueden responderse a estas argumentaciones: la primera, que el concepto de culpabilidad no puede basarse en la contraposición de la «realidad» frente a las «apariencias», contraposición sin sentido cuando se refiere a un código como el del honor-opinión basado precisamente en las apariencias. Desde este punto de vista doña Mencía no es inocente en absoluto: sus acciones son culpables en tanto crean una serie de apariencias capaces de deshonrar a su marido (y si el honor radica en la opinión, las apariencias son verdaderas realidades pues en la apariencia se basa el honor). La segunda es que, ciertamente, doña Mencía realiza una serie de acciones que atentan contra el honor de don Gutierre. Este encuentra pistas (no las cree encontrar como dice Petro del Barrio ignorando el texto calderoniano): halla un hombre en su casa, descubre el puñal que luego identifica como posesión de don Enrique, su mujer escribe a don Enrique papeles que el marido sorprende, en la oscuridad se dirige a él confundiéndolo con don Enrique y llamándolo «Alteza», lo que confirma para don Gutierre la relación entre Mencía y el infante... Nada de esto se inventa don Gutierre: ninguna de estas «pistas» es imaginaria...

28 Insisto: no hablo tanto de culpabilidad en sentido moral, sino en cuanto responsable de la deshonra del marido según el código del honor.

29 Petro del Barrio, 2006, pp. 109-110. Sobre la inocencia o culpabilidad de Mencía, con numerosa bibliografia, ver el estudio de Armendáriz, 2007, pp. 165-179.

30 Bandera, 1997, pp. 172-173.

31 Marshall, 2003, cap. II. 
Don Gutierre no busca excusas falsas para matar a su mujer: en realidad procura evitar la situación fatal a la que se ve empujado cada vez con más fuerza. No se complace en la muerte de Mencía, se resiste a ejecutarla. Acude al rey, advierte a su mujer... todo es en vano. Todos los que le rodean le fallan: la criada traidora, una esposa orgullosa de su honor y sin prudencia ninguna, un infante que desprecia el honor de los demás, un rey incompetente...

Me parece muy justa y significativa la caracterización del personaje que traza Ana Armendáriz ${ }^{32}$ :

¿Quién y cómo es Gutierre? Es un héroe o persona que realiza un sacrificio heroico o dolorosamente heroico, más bien. Lo que no excluye otra denominación oportuna: víctima de un sistema del honor - tal y como aparece en la comedia-, que con sus exigencias causa su tragedia personal y familiar, aunque su responsabilidad como noble, su dignidad humana y su lealtad al rey le hacen asumir las obligaciones de su clase; víctima también, por qué no, de un monarca pusilánime que falla en su cometido principal, proteger a su vasallo...

En suma, sobre don Gutierre descargan todos la obligación de la honra y él la acepta. No se trata, pues, de obsesiones celosas, de enfermedades del espíritu ni de impulsos asesinos de un personaje monstruoso: se trata de una estructura de presión social en la que lo importante para el sistema no es la muerte de las mujeres sino el honor de los maridos, que no es exactamente lo mismo ${ }^{33}$. ¿Qué es lo que protege este código del honor, por qué depende de su mantenimiento la estabilidad social?

A mi juicio el honor es otro nombre de la autoridad que corresponde a un noble, y esta autoridad reconocida (reputación o respeto) es lo que debe asegurar cada miembro del estamento en bien de la estabilidad del cuerpo común. La pérdida de la autoridad nobiliaria

32 Armendáriz, 2007, p. 164.

${ }^{33}$ Los casos de honra conyugal son los más eficaces dramáticamente, pero no son los únicos ni el problema del honor se puede interpretar como una disimulación del problema de los celos. Téngase en cuenta que además de la conducta de las mujeres hay otras fuentes de deshonra (desmentidos, bofetadas, insultos...) que obligan igualmente a la venganza. 
—es irrelevante quién la provoque y por qué medios ${ }^{34}$ - destruiría la organización social, borraría las diferencias, confundiría todos los estratos y provocaría el caos y la violencia generalizada. La situación ideal sería no ver nunca cuestionada esa autoridad, es decir, una situación en la que a nadie se le ocurriera atentar contra ella, pero si ese atentado se produce la reparación debe ser lo más discreta posible para evitar la difusión de la deshonra. El deshonrado debe recuperar su nivel de autoridad demostrando con la venganza que el honor es un territorio protegido con peligro de muerte para los transgresores. No es extraño que los principales dramas de honor coincidan con una época de crisis y erosión de la estructura social, denunciada reiteradamente en otros textos como la novela picaresca (buen ejemplo es el Buscón de Quevedo). Tampoco que en las comedias el rey legitime las venganzas de la honra que intentan fortalecer un sistema en cuya cima está precisamente el monarca.

Una última observación conviene hacer sobre el desarrollo de este rito sacrificial exigido por la colectividad. Don Gutierre, como otros maridos de Calderón, antes de matar a Mencía, expresa sus quejas sobre «el bárbaro rito». Si estoy en lo cierto al identificar la duplicada víctima propiciatoria la protesta apunta la debilidad del código del honor, que ya no es capaz de lograr la voluntariedad de la víctimaverdugo, requisito esencial, como recuerdan los antropólogos, para el buen funcionamiento del ritual ${ }^{35}$.

Otros detalles de la comedia confirman la inestabilidad, y sugieren las tensiones que amenazan a todos, en especial el enfrentamiento de los dos hermanos reales, con las facciones de don Pedro y don Enrique $^{36}$ (quien acabará con la vida de su hermano en el campo de Montiel, dato histórico que el espectador de la comedia tendría presente como horizonte de recepción).

${ }^{34}$ Solo el rey podría escapar a las consecuencias, pero del rey abajo, ninguno... La manera más violenta de perder esa autoridad es sin duda la infidelidad (o apariencias de tal) de la esposa.

${ }^{35}$ Ver Petro del Barrio, 2006, p. 33 para el requisito de la voluntariedad y Bandera, 1997, p. 174 para el resquebrajamiento del sistema que implica la protesta de los individuos obligados por el código del honor, y la falta de la unanimidad violenta.

${ }^{36}$ Ver pasajes pertinentes en vv. 26 y ss., o 2266 y ss. 
El ciclo de la violencia en el drama de honor no está neutralizado: el mecanismo sustentador de la regulación social no parece funcionar eficazmente.

El lenguaje de la violencia: la palabra y la escena

Guntert $^{37}$ ha recordado los juicios de Moratín padre sobre el hipogrifo de Rosaura, es decir, sobre el lenguaje poético de Calderón. Pontifica el ilustrado poeta:

Esto de olvidar la naturaleza, y en vez de retratarla desfigurarla, es muy frecuente en don Pedro Calderón. El principio de su comedia La vida es sueño lo acredita. Yo quisiera saber, si una mujer cae despeñada por un monte con un caballo, en vez de quejarse donde le duele y pedir favor le dice todas aquellas impropias pedanterías, que las entiende el auditorio como el caballo. Si algún su apasionado cayese por las orejas, llámele hipogrifo violento, y verá como se alivia.

Al buen Moratín — no solo a él- le parece excesivo el lenguaje de Rosaura y reclama la sencillez expresiva y natural. Pero no percibe lo poco que tiene de «natural» la primera escena de La vida es sueño: una mujer vestida de hombre que cae despeñada, arrojada entre riscos por un caballo desbocado ${ }^{38}$. No se me ocurre qué frases sencillas y naturales pudiera decir en tales circunstancias. Me parece que Calderón tiene más claro que Moratín el tipo de lenguaje que responde a la categoría de la acción teatral.

Si se revisan las comedias que vengo mencionando resulta obvia la construcción sistemática del lenguaje de la violencia, basado en algunos rasgos fundamentales: hipérboles e imágenes del horror (entre ellas las fórmulas de insultos y los nacimientos teriomorfos), repertorios simbólicos especializados (volcanes, terremotos, tormentas, eclipses, cataclismos cósmicos, enfermedades...), y emblemas de la violencia (particularmente animales venenosos y feroces).

${ }^{37}$ La cita de Moratín en Guntert, 2002, p. 504.

38 Un comentario - más agudo que el de Moratín-, que pone de relieve la funcionalidad teatral de esta primera escena y sus detalles, en Rico,1999. 
Un buen ejemplo de hipérboles es el aviso de Gutierre a Mencía, verdadero catálogo de «hechos inhumanos»:

\author{
a tener... ¿qué son celos? \\ átomos, ilusiones, y desvelos;... \\ no más que de una esclava, una criada, \\ por sombra imaginada, \\ con hechos inhumanos, \\ a pedazos sacara con mis manos \\ el corazón y luego \\ envuelto en sangre, desatado en fuego \\ el corazón comiera \\ a bocados, la sangre me bebiera, \\ el alma le sacara, \\ y el alma, ¡vive Dios!, despedazara, \\ si capaz de dolor el alma fuera. (vv. 2019-2031)
}

Fácil sería acumular ejemplos semejantes, con sangre, fuego, ira, explosiones y destrucciones. El rey Enrique (La cisma de Ingalaterra) se deshace en su pasión:

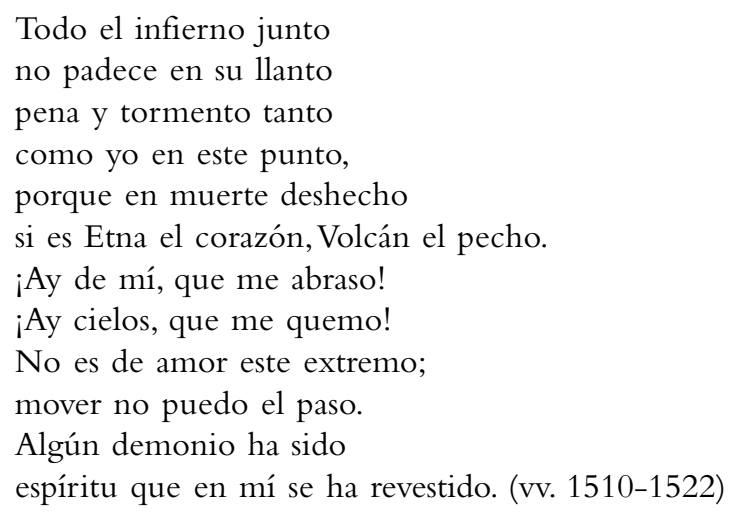

Infiernos, rayos y volcanes expresan el horror de Eusebio al percatarse de que Julia es su hermana y está a punto de cometer un incesto (La devoción de la cruz, vv. 1600-1605), y Julia pretende con sus delitos dar asombros al cielo, espantos al mundo, «horror al mismo pecado / y terror al mismo infierno» (vv. 1767-1771). Los volcanes constituyen una imagen favorita del lenguaje calderoniano de la vio- 
lencia: añádanse a los ejemplos citados, el de Segismundo («un Volcán, un Etna hecho»), el de Egerio en El purgatorio de San Patricio ("que es Etna el corazón, Volcán el pecho», p. 179), o, en la misma comedia (p. 189) el de Ludovico, cuyas entrañas son «Volcanes y Mongibelos». Otra es la enfermedad: melancolía patológica, rabia, frenesí o peste son imágenes frecuentes para la violencia, que se contagia, ciertamente, como la peste o la rabia.

A los nacimientos portentosos acompañan cataclismos agoreros. Al del mismo Ludovico asisten los siete planetas descompuestos (p. 182); en el de Segismundo - cuya madre muere del parto- el sol tinto en sangre entra en desafio con la luna en un horrendo eclipse acompañado de otros fenómenos espantosos:

Los cielos se escurecieron, temblaron los edificios, llovieron piedras las nubes, corrieron sangre los ríos. (vv. 696-699)

La terrible Semíramis de La hija del aire viene al mundo entre convulsiones del cosmos que anuncian su futura condición y trayectoria de violencia extrema: nace, en efecto, en tal horóscopo

que estaba todo

ese globo cristalino,

por un comunero eclipse,

que al sol desposeer le quiso

del imperio de los días,

parcial, turbado y diviso;

tanto que entre sí lidiase

sobre campañas de vidro

las tropas de las estrellas,

las escuadras de los signos,

acometiéndose airados

y ensangrentándose a visos.

En civil guerra los dioses

vieron ese azul zafiro

en sus ejes titubeando,

desplomado de sus quicios. (vv. 853-867) 
No hace falta acopiar más textos de esta clase, que abundan en los dramas de Calderón.

Otro rasgo importante del lenguaje de la violencia es el uso de los emblemas. Uno reiterado, de fuerte sentido político y moral, es el del caballo, que cuando está bien regido con freno y riendas es símbolo de la prudencia, pero que desbocado expresa la ceguera pasional, intelectual y moral. La descripción de la reina Cenobia (La gran Cenobia) que hace Decio expresa en su dominio del caballo su condición moral:

Cenobia, que a Palas parecía tan firme en un caballo, que creyera que a los dos un espíritu regía, porque mostraba aunque de furia lleno que se pudiera gobernar sin freno. (vv. 397-401)

Muy diferente es el hipogrifo violento que descabalga a Rosaura en La vida es sueño, el caballo desbocado con que comparan Clotaldo o Basilio a Segismundo, el bruto que desmonta al infante Enrique en El médico de su honra, el animal enloquecido que rompiendo el freno arroja al tirano Focas en En esta vida todo es verdad y todo mentira, o el «monstruo de los elementos» desbocado que acaba colgando a Absalón de las ramas del bosque (Los cabellos de Absalón, p. 863)... Todos estos caballos tienen un valor emblemático evidente para los espectadores del Siglo de Oro ${ }^{39}$.

El bestiario fabuloso, otra de las áreas privilegiadas por la emblemática, es elemento favorito de Calderón: el mar de la corte se puebla de sirenas como Ana Bolena (La cisma de Ingalaterra), y el vulgo se compara con una hidra, monstruo de siete cervices (La hija del aire; Los cabellos de Absalón). Segismundo y Semíramis son, entre otros personajes calderonianos, calificados de víboras por haber matado a su madre al nacer... Todas estas menciones (serpientes, monstruos - otro término clave-, basiliscos, áspides, tigres hircanos...) se basan en creencias y tópicos relacionados con estos animales, que se extienden ampliamente por los libros de emblemas y bestiarios. Todos los ani-

${ }^{39}$ Ver caballos desbocados con varios matices en Alciato, Covarrubias Horozco... Ver Bernat y Cull, 1999, núms. 260, 261, 266... y el artículo que le dedica Valbuena en su recopilación de 1997. 
males pertenecientes a este ámbito comparten la ferocidad letal y la capacidad de contagio venenoso.

La violencia no se contiene solo en lo verbal: la representación escénica explora las exhibiciones terroríficas de valor didáctico, patético o ambos, sin retroceder ante las composiciones truculentas. Calderón dispone a menudo el escenario para causar la máxima impresión en el espectador. Baste, limitándome a la cita por brevedad, recordar la cabeza cortada de Lisías (Judas Macabeo, p. 382); las puñaladas mortales de Decio a Aureliano (La gran Cenobia) o de Tuzaní a Garcés (Amar después de la muerte), y de Ludovico a Dorotea (El purgatorio de San Patricio); o la exposición del cuerpo decapitado de Ana Bolena en La cisma de Ingalaterra:

Vase. Tocan chirimías y clarines y salen a la jura los que pudieren, y el rey y la infanta, que suben en un trono, a cuyos pies, en lugar de almohada, ha de estar el cuerpo de Ana Bolena, cubierto con un tafetán, y, en estando sentados, la descubren. (p. 236)

Las exhibiciones de los cuerpos castigados se reiteran con detalles que privilegian el efectismo dramático, con apariciones repentinas, al descorrerse la cortina del hueco central o abrirse unas puertas que dejan ver el lastimoso espectáculo, como evidencian las instrucciones reiteradas en las acotaciones de descúbrese, aparece, etc.: así se ofrecen los cadáveres del capitán Ataide (El alcalde de Zalamea) o don Lope hijo (Las tres justicias en una):

Crespo

Si no creéis

que es esto, señor, verdad, volved los ojos, y vedlo.

Aquéste es el capitán. (vv. 2694-2697)

Aparece dado garrote, en una silla, el capitán.

Abre las puertas, que serán las de en medio del teatro y vese a don Lope, hijo, en una silla, como dado garrote, y un papel en la mano, $y$ dos velas a los lados.

(Las tres justicias en una, p. 709)

El cuerpo de Absalón se descubre pendiente de los cabellos con tres lanzas atravesadas (Los cabellos de Absalón, p. 863), y antes se ha descubierto en una mesa revuelta el cuerpo ensangrentado de Amón (p. 
849). Ninguna composición más impresionante que el túmulo de doña Mencía en El médico de su honra según nos lo describe el atemorizado barbero:

LUDOVICO

Una imagen

de la muerte, un bulto veo, que sobre una cama yace; dos velas tiene a los lados y un crucifijo delante. Quién es no puedo decir, que con unos tafetanes el rostro tiene cubierto. (vv. 2575-2580)

\section{Final}

Si la violencia de la comedia española del Siglo de Oro —en este caso concreto la calderoniana- no puede menos que llamar la atención del lector (o espectador), como apunta Petro del Barrio ${ }^{40}$, no se deberá a una supuesta exclusividad de dicho componente, atribuible (como piensan algunos) a la Inquisición u otras opresiones locales. Baste remitir a los dramas históricos de Shakespeare o a la tragedia griega para negar que la violencia caracterice especialmente al teatro español del Siglo de Oro, y desmontar afirmaciones como las de Patricia Marshal según las cuales el gobierno español y sobre todo la Inquisición usan los mecanismos violentos (castigos, encarcelamientos, torturas, censuras de gestos y comportamientos sexuales, etc.) como instrumentos de dominio y control típicos de la España del XVII ${ }^{41}$.

Más bien sucede que la violencia es innata al individuo y a la misma sociedad humana, y se manifiesta en todos los lugares y circunstancias. La máquina funciona sin parar: lo que hace Calderón de modo magistral es explorar ese funcionamiento, cuestionar sus legitimaciones o falsificaciones, examinar las adaptaciones del ritual de sacrificio cuyas debilidades se evidencian en la ambigüedad del código del honor,

40 Petro del Barrio, 2006, p. 13.

${ }^{41}$ Entiéndase: Marshall tiene razón al señalar estos instrumentos violentos de control, pero claro está que no son característicos de la España de la Inquisición, sino procedimientos universales. 
desvelar las múltiples caras de las víctimas y los verdugos, con personajes que a veces simultanean ambos papeles... ofrecer, en suma, un cuadro lúcido, sin disimulos o paliativos, de lo que viene siendo, desde el principio de la historia, una carga insoportable que el hombre tiende a ocultar o dignificar: esa violencia que en el escenario calderoniano sobrecoge y aterra, provocando, quizá, una reflexión en el espectador sobre este fenómeno cuya necesaria superación parece llena de obstáculos para la especie. 


\section{Bibliografía}

Antonucci, F., Introducción a Calderón, P., La vida es sueño, ed. F. Antonucci, Barcelona, Crítica, 2008.

Arellano, I., "Cervantes en Calderón», Anales cervantinos, 35, 1999a, pp. 935.

- Convención y recepción. Estudios sobre el teatro del Siglo de Oro, Madrid, Gredos, 1999b.

- Calderón y su escuela dramática, Madrid, Laberinto, 2001.

Armendáriz, A., Introducción a Calderón, P., El médico de su honra, ed. A. Armendáriz, Madrid, Iberoamericana, 2007.

Bances Candamo, F. A., Teatro de los teatros, ed. D. W. Moir, London, Tamesis, 1970.

Bandera, C., Mimesis conflictiva, Madrid, Gredos, 1975.

- El juego sagrado, Sevilla, Universidad de Sevilla, 1997.

Bernat Vistarini, A. y J. T. Cull, Emblemas españoles ilustrados, Madrid, Akal, 1999.

Bodini, V., Segni e simboli nella Vida es sueño, Bari, Adriatica, 1968.

Calderón, P., Amar después de la muerte, ed. E. Coenen, Madrid, Cátedra, 2008.

- El alcalde de Zalamea, ed. J. M. Escudero, Madrid, Iberoamericana, 1998.

- El mayor monstro los celos, ed. E. W. Hesse, Madison, The University of Wisconsin Press, 1955.

- El médico de su honra, ed. A. Armendáriz, Madrid, Iberoamericana, 2007.

- El pintor de su deshonra, en Obras completas. Dramas, ed. Á.Valbuena Briones, Madrid, Aguilar, 1987.

- El príncipe constante, en Calderón, P., Primera parte de comedias, ed. L. Iglesias Feijoo, Madrid, Biblioteca Castro, 2006.

- El purgatorio de San Patricio, en Obras completas. Dramas, ed. Á. Valbuena Briones, Madrid, Aguilar, 1987.

- El sitio de Bredá, en Calderón, P., Primera parte de comedias, ed. L. Iglesias Feijoo, Madrid, Biblioteca Castro, 2006.

- Judas Macabeo, en Calderón, P., Segunda parte de comedias, ed. S. Fernández Mosquera, Madrid, Biblioteca Castro, 2007.

- La cisma de Ingalaterra, ed. J. M. Escudero, Kassel, Reichenberger, 2001.

- La devoción de la cruz, ed. M. Delgado, Madrid, Cátedra, 2000.

- La gran Cenobia, ed. M. Pannale, en prensa.

- La hija del aire (primera y segunda parte), ed. U. Baztán, en prensa.

- La vida es sueño, ed. F. Antonucci, Barcelona, Crítica, 2008.

- Las tres justicias en una, en Obras completas. Dramas, ed. Á.Valbuena Briones, Madrid, Aguilar, 1987. 
- Los cabellos de Absalón, en Obras completas. Dramas, ed. Á.Valbuena Briones, Madrid, Aguilar, 1987.

Delgado, M., Introducción a Calderón, P., La devoción de la cruz, ed. M. Delgado, Madrid, Cátedra, 2000.

Escudero, J. M., Estudio preliminar a Calderón, P., La cisma de Ingalaterra, ed. J. M. Escudero, Kassel, Reichenberger, 2001.

Girard, R., La violencia y lo sagrado, Barcelona, Anagrama, 1983.

Guntert, G., «La vida es sueño: algo más sobre el hipogrifo violento», en Calderón 2000, ed. I. Arellano, Kassel, Reichenberger, 2002, II, pp. 495508.

Hall, H. B., «Segismundo and the rebel soldier», Bulletin of Hispanic Studies, 45, 1968, pp. 189-200.

Llano, A., Deseo, violencia, sacrificio, Pamplona, EUNSA, 2004.

Marshall, P. A., Anatomía y escenificación. La representación del cuerpo humano en el teatro de Calderón de la Barca, New York, Peter Lang, 2003.

Morr, D. W., Introducción a Bances Candamo, F. A., Teatro de los teatros, ed. D. W. Moir, London, Tamesis, 1970.

Petro del Barrio, A., La legitimación de la violencia en la comedia española del siglo XVII, Salamanca, Universidad de Salamanca, 2006.

Rico, F., «El teatro es sueño», en Calderón, P., La vida es sueño, ed. G. Serés, Barcelona, Planeta, 1999, pp. 12-14.

Rojas, F. de, La Celestina, ed. F. J. Lobera, G. Serés, P. Díaz Mas, C. Mota, Í. Ruiz y F. Rico, Barcelona, Crítica, 2000.

Valbuena Briones, Á., "El emblema simbólico de la caída del caballo», en Calderón y la comedia nueva, Madrid, Espasa Calpe, 1977, pp. 88-105.

Vitse, M., "Calderón trágico», Anthropos. Extra 1, 1997, pp. 61-64.

- "Gutierre Alfonso de Solís», en Calderón 2000, ed. I. Arellano, Kassel, Reichenberger, 2002, I, pp. 163-86.

- Segismundo et Serafina, Toulouse, Université de Toulouse-Le Mirail, 1980.

- Élements pour une théorie du théâtre espagnol du XVII siècle, Université de Toulouse-Le Mirail, France Ibérie Recherche, 1988. 
